\title{
Akciğerin Büyük Hücreli Nöroendokrin Karsinomundaki cerrahi sonuçlarımız
}

\section{Surgical outcomes of Large Cell Neuroendocrine Carcinoma of the lung}

\author{
Fazlı YANIK*@, Yekta ALTEMUR KARAMUSTAFAOĞLU@, Yener YÖRÜK回 \\ Trakya Üniversitesi Tıp Fakültesi Göğüs Cerrahisi Bölümü, Edirne/TÜRKiYE
}

\section{Öz}

Amaç: Akciğerin büyük hücreli nöroendokrin karsinomları (BHNK) yüksek dereceli nadir tümörlerdir ve küçük hücreli akciğer kanserine benzer klinik ve biyolojik özellikler taşırlar. Bu çalışmada histopatolojik tanısı akciğerin BHNK'u olan olgulardaki cerrahi sonuçlarımızı, prognozu ve sağkalımı irdeledik.

Gereç ve Yöntemler: Haziran 2012-Haziran 2018 tarihleri arasında rezeksiyon yapılan ve patolojik tanıları BHNK olarak

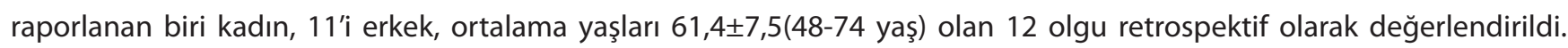
Prognoz, yaş, cins, sigara içme hikayesi, tümör çapı, tanı tedavi modaliteleri, cerrahi sonuçlar ve sağkalım hastane kayıtlarından analiz edildi.

Bulgular: Sekiz olguda tümör sağ hemitoraks yerleşimli iken, dört olguda sol hemitoraks yerleşimliydi. 11 olguda mediastinoskopi ve anatomik akciğer rezeksiyonu ile mediastinal lenf nodu diseksiyonu uygulandı. T1 evreli bir olgu ise bilgisayarlı toraks tomografisinde mediastende patolojik lenf nodu olmadığı için, mediastinoskopi yapılmadan, video yardımlı lobektomi ve mediastinal lenf nodu diseksiyonu uygulandı. Olguların yedisi (\%58) takipler sırasında metastaz veya tümör progresyonu nedeniyle kaybedildi. Ortalama tümör çapı, ortalama sağ-kalım süresi, hastalıksız sağ-kalım

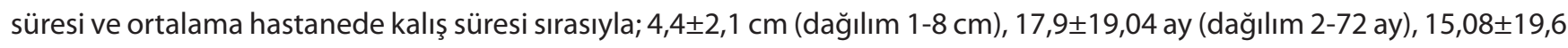
ay ( dağılım 1-72 ay ) ve 6,4 $\$ 3,6$ gün (4-12 gün) olarak hesaplandı. Postoperatif mortalite görülmedi. iki(\%16) olguda komplikasyon (atelektazi ve yara yeri enfeksiyonu) görüldü.

Sonuç: Tedavi ve sağ-kalım açısından küçük hücreli akciğer kanserine benzer özellikler taşısa da, tedavi stratejisinde tam olarak bir fikir birliğinin sağlanamamıştır. Günümüzde küratif anatomik rezeksiyonlar ve beraberinde eklenecek onkolojik tedaviler uzun dönem sağ-kalım için tek şans gibi gözükmektedir. Ancak bu nadir görülen tümörlerle ilgili daha geniş vaka serilerini içeren çalışmalara ihtiyaç vardır.

Anahtar kelimler: Akciğer; tümör; büyük hücreli nöroendokrin tümör

Sorumlu Yazar*: Fazlı Yanık, Trakya Üniversitesi Tıp Fakültesi Göğüs Cerrahisi Bölümü, Edirne/TÜRKIYE

E-mail: fazliyanik@hotmail.com

ORCID: 0000-0002-8931-5329

Gönderim: 06.11.2018 Kabul: 27.12.2018

Doi: 10.18663/tjcl.479216 


\begin{abstract}
Aim: 'Large cell neuroendocrine carcinoma of the lung' ( $L C N E C L)$ is high-grade rare tumors and has clinical and biological characteristics similar to small cell lung cancer. In this study, we evaluated the surgical results, prognosis and survival of the patients with histopathologically LCNECL.
\end{abstract}

Materials and Methods: Twelve patients, one female and 11 male, with a mean age of 61,4 $\pm 7,5(48-74$ years), who were reported as LCNECL between June 2012 and June 2018 was performed resection, were evaluated retrospectively. Prognosis, age, sex, smoking history, tumor size, diagnostic treatment modalities, surgical outcomes and survival was analyzed from hospital records.

Results: While in eight cases the tumor was located in the right hemithorax, in four cases was left hemithorax. Mediastinoscopy and anatomic lung resection with mediastinal lymph node dissection were performed in 11 cases. In one case with T1 stage, video-assisted lobectomy and mediastinal lymph node dissection were performed without mediastinoscopy because there was no pathological lymph node in the mediastinum in chest computerized tomography. Seven patients (58\%) died due to tumor progression or metastasis during follow-up. The median tumor size, median survival time, median disease-free survival time and median lenght of hospital time were $4.4 \pm 2.1 \mathrm{~cm}$ (range1-8cm), 17.9 \pm 19.04 months(range2-72months), $15,08 \pm 19.6$ months(range1-72months) and 6,4 $\pm 3,6$ days(4-12days), respectively. There was no postoperative mortality. Two(16\%) patients with complications (atelectasis and wound infection) were observed.

Conclusion: Although they have similar features with small cell lung cancer in terms of treatment and survival rates, no consensus have been identified in their treatment strategy. Today, curative anatomic resections and accompanying oncological therapies seem to be the only chance for long-term survival. However, there is a need for studies including larger case series about these rare tumors

Key words: Lung; tumor; large cell neuroendocrine tumor

\section{Giriş}

"Nöroendokrin tümörler; gastroenterik, hepatopankreatobiliyer, bronkopulmoner ve ürogenital sistemin nöroendokrin hücrelerinden köken alan tümörlerdir. Bulundukları bölgeye ve salgıladıkları hormonlara göre klinik oluşturabilir ve nadir görülürler. Akciğerin büyük hücreli nöroendokrin karsinomları (BHNK) yüksek gradeli tümörlerdir ve küçük hücreli akciğer kanserine (KHAK) benzer klinik ve biyolojik özellikler taşırlar. BHNEK klinik olarak KHAK şeklinde davrandığı için erken evrede dahi cerrahi yeterli değildir. Adjuvan onkolojik tedavi gereklidir(1,2). Dünya Sağlık Örgütünün (WHO) son sınıflamasına göre pulmoner nöroendokrin tümörler, karsinoid tümör (tipik ve atipik), küçük hücreli akciğer karsinomu (KHAK), büyük hücreli nöroendokrin karsinoma (BHNEK) ve yeni bir tür olan Diffüz İdiyopatik Pulmoner Nöroendokrin Hücre Hiperplazisi (DIPNEHH) olarak sınıflandırılmaktadır. DIPNEHH bronşektazi ve fibrozis içeren, bronşialitis obliteransıla ilişkili prekanseröz bir durumdur(3). BHNK kötü prognoza sahip, ender rastlanan son derece agresif karakterde bir akciğer kanseri alt türüdür (4). Bu çalışmada histopatolojik tanısı akciğerin BHNK'u olan olgulardaki cerrahi sonuçlarımızı, prognozu ve sağkalımı irdeledik.

\section{Gereç ve Yöntemler}

Kliniğimizde Haziran 2012-Haziran 2018 tarihleri arasında akciğer kanseri nedeniyle rezeksiyon uygulanan 184 olgudan histopatolojik tanısı BHNK olarak raporlanan biri kadın,11'i

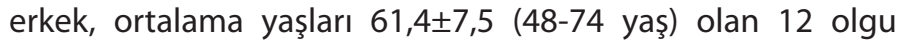
retrospektif olarak değerlendirildi. Operasyon öncesi tüm olgulara akciğer grafisi, kontrastlı toraks BT (Bilgisayarlı Tomografi), PET-BT (Pozitron Emisyon Tomografisi) ve kranial MR (Manyetik Rezonans görüntüleme) çekildi. KHDAK tanısı operasyon öncesi beş olguda tru-cut biyopsi, dört olguda FOB, üç olguda torakotomide frozen inceleme ile koyuldu. Histopatolojik inceleme sonunda tüm olgularda patolojik tanı BHNEK olarak raporlandı. Yaş, cinsiyet, PET-BT bulguları, histopatolojik tip, hastalık evresi, cerrahi sonuçlar, sağkalım, uygulanan onkolojik tedaviler, hastalıksız sağ-kalım, nüks durumu incelendi.

\section{İstatiksel Analiz}

SPSS, versiyon 20.0, SPSS Inc., Chicago, IL, USA programI kulanılarak yapıldı. Tanımlayıcı istatistiklerde, sürekli değişkenler ortalama \pm standart sapma, kategorik değiş̧kenler yüzde biçiminde ifade edildi.

\section{Bulgular}

Sekiz olguda tümör sağ, dört olguda sol hemitoraks yerleşimliydi. 11 olguda mediastinoskopi ve anatomik akciğer rezeksiyonu, mediastinal lenf nodu diseksiyonu uygulandı. 
Yedi olguda servikal mediastinoskopi ile operasyona başlandı. Frozen kesitlerinde mediastinal lenf nodlarının negatif raporlanması üzerine aynı seansta rezeksiyona devam edildi. Dört olguda ise farklı seanslarda mediastinoskopi ve rezeksiyon uygulandı. T1 evreli bir olgu ise, mediastende patolojik lenf nodu olmadığı için mediastinoskopi yapılmadan, video yardımlı lobektomi ve mediastinal lenf nodu diseksiyonu uygulandı (Tablo 1). Olguların tamamının sigara öyküsü mevcuttu (ortalama 22,6 paket/yıl). Illk hastaneye başvuru semptomları yedi olguda öksürük, üç olguda göğüs ağrısı, bir olguda hemoptizi ve bir olguda yan ağrısı şeklindeydi. Tümörlerin 10'u (\%83) periferik yerleşimliyken, ikisi (\%17) santral yerleşimliydi. 12 olgunun çekilen PET-BT'lerinde ana kitledeki ortalama SUVmax (Standardize maksimal tutulum değeri) değeri 12,4 \pm 10,1 (7,5-26,2) olarak bulundu, kitle dışında metastatik bir odak saptanamadı. Ortalama tümör çapı 4,4 $\pm 2,1 \mathrm{~cm}$ (dağılım 1-8 cm)' idi. Üç olguda neoadjuvan kemoterapi, tüm olgulara adjuvan kemoterapi uygulandı. Kemoterapi rejimi olarak etoposide $100 \mathrm{mg} / \mathrm{m}^{2}$ (180 mg/gün), cisplatin $80 \mathrm{mg} / \mathrm{m}^{2}$ (145mg/gün) kullanıldı. Yedi (\%58) olguda postoperatif izlem sırasında metastataz gelişmesi üzerine tedaviye palyatif radyoterapi eklendi (Tablo 1). Ortalama

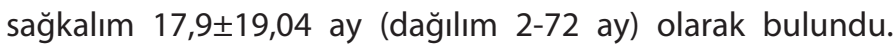
Hastalıksız sağkalım ise $15,08 \pm 19,6$ ay (dağılım 1-72 ay ) olarak hesaplandı. Ortalama izlem süresi 18,9 \pm 14,5 (2-72) ay ve ortalama hastanede kalış süresi $6,4 \pm 3,6$ gün (4-12 gün) idi. Postoperatif erken dönem mortalite görülmedi. İki (\%16) olguda komplikasyon görüldü. Bunlar bir olguda bronkoskopi gerektiren atalektazi, bir olguda antibiyoterapi ve pansuman ile tedavi edilen yara yeri enfeksiyonu gelişti. Olguların yedisi (\%58) takipler sırasında metastaz ve/veya tümör progresyonu nedeniyle kaybedildi (Tablo 1, Resim 1).

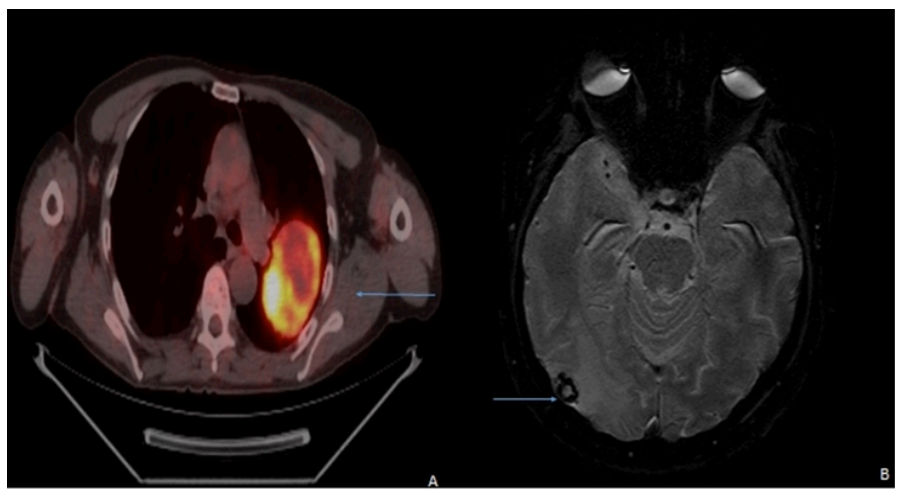

Resim 1) A: BHNK nedeniyle sol pnömonektomi uygulanan hastanın preoperatif dönemdeki PET-BT görüntüsü, sol santral yerleşimli, 4×5 cm boyutlarında kitlesel lezyon, SUVmax değeri: 12,7olarak ölçüldü, mavi ok ile işaretli B: Aynı hastanın postoperatif 14. Ayında baş ağrısı nedeniyle çekilen kranial MR'ında sağ oksipital lobda 2x1 cm'lik metastatik lezyon tespit edildi, mavi ok ile işaretli.

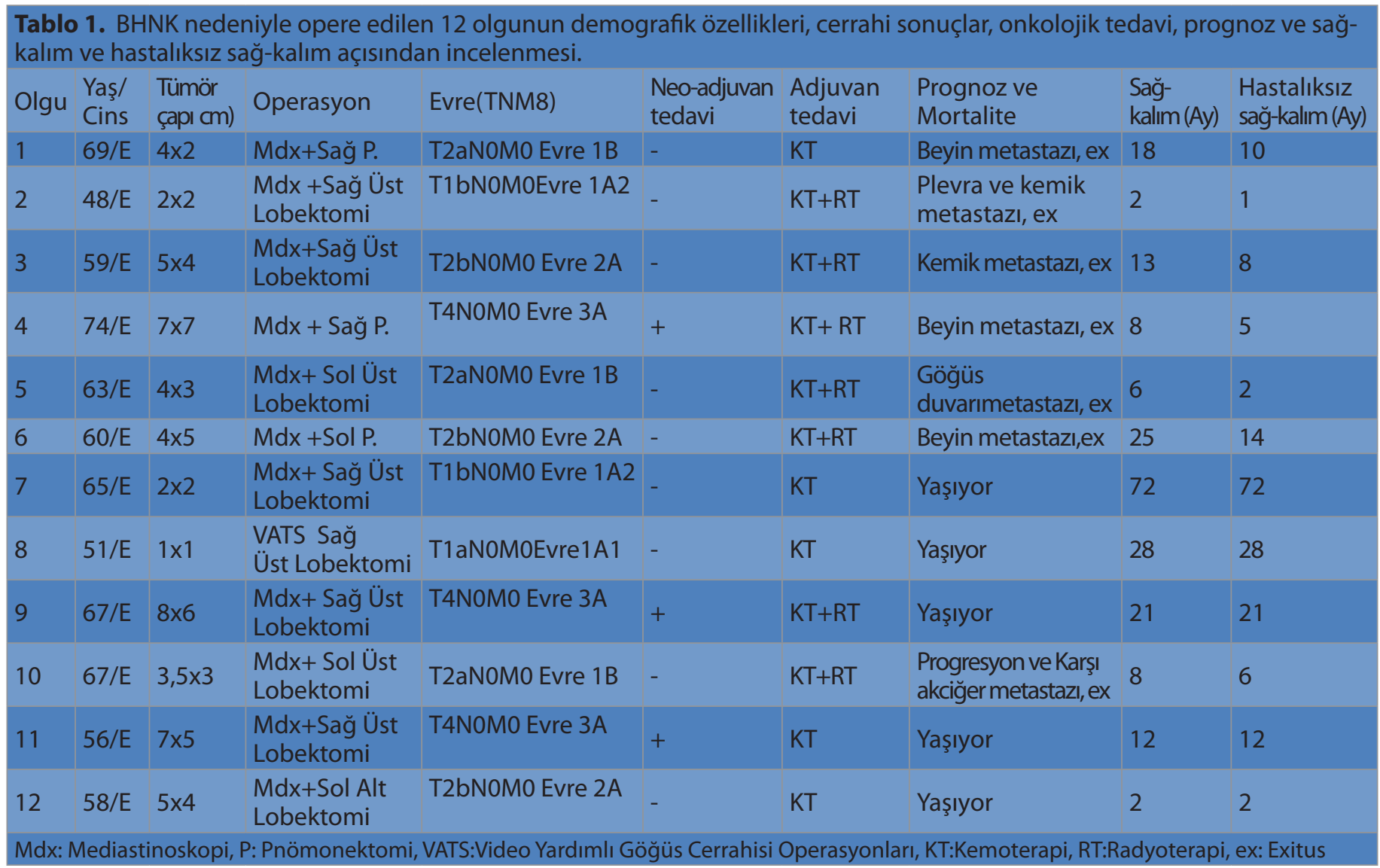


Histopatolojik ve immunohistokimyasal incelemeler sonunda; tümörlerin ortak özelliği, nöroendokrin morfoloji içeren küçük hücreli dışı akciğer karsinomu özelliğine sahip olmasıydı. Tümör organoid veya trabeküler patern içeren, rozet benzeri özellikler taşıyan, periferal palizatlanma gösteren geniş nekroz alanları içeren, belirgin nükleoluslu, büyük poligonal hücrelerden oluşmaktaydı. Tümünde mitoz sayısı $\geq 11 / 10$ büyük büyütmede idi. BHNK nedeniyle opere edilen 12 olgunun demografik özellikleri, cerrahi sonuçlar, onkolojik tedavi, prognoz ve sağ-kalım ve hastalıksız sağ-kalım açısından incelenmesi Tablo 1'de özetlendi.

\section{Tartışma}

Nöroendokrin akciğer kanserleri küçük hücreli akciğer kanseri, BHNK, tipik karsinoid tümör ve atipik karsinoid tümör olarak sınıflandırılabilir. BHNEK küçük hücreli akciğer kanseri ile benzer özellikler gösterir ve nöroendokrin özellikler gösteren yüksek dereceli bir tümördür. Bu dört tip benzer histopatolojik özellikler gösterdiği için küçük biyopsi örnekleri ile tanısını koymak zordur ve mutlaka ayırıcı tanıya gidilmelidir $(1,5)$. Olgularımızın tamamında definitif tanı postoperatif rezeksiyon materyalinin histopatolojik incelemesiyle konuldu.

BHNEK yoğun sigara içen, 60-70 yaş erkeklerde daha fazla görüldüğünü bildiren yayınlar mevcuttur. $(5,6)$. Literatürle uyumlu olarak çalışmamızdaki olguların \%92'si erkekti ve hepsi yoğun sigara kullanım öyküsüne sahipti, ortalama yaş ise 61,4 47,5 (48-74 yaş) idi.

Tüm akciğer tümörlerinin yaklaşık \%3'ünü BHNK oluşturur. Cerrahi rezeksiyon uygulanan akciğer kanserleri içerisinde BHNEK insidansı ise \%2 kadardır. Küçük biyopsi materyallerindeki tanı zorluğu nedeniyle, insidansının daha yüksek olabileceği tahmin edilmektedir. Kötü diferansiasyon (farklılaşma) gösteren yüksek lenf nodu ve ekstratorasik metastaz oranına sahip, kötü prognozlu tümörlerdir $(7,8)$. Çalışmamızda altı yıllık dönemde akciğer kanseri nedeniyle rezeksiyon uygulanan tümörlerin \% 6,5'ini BHNEK oluşturmaktaydı.

Fournel ve ark.(7)'nın 10 yıllık cerrahi deneyimlerini analiz ettikleri 63 BHNEK'li olguyu içeren çalışmalarında, postoperatif mortalitenin \% 1,6 olduğunu, olguların \%70'inin adjuvan tedavi almasına rağmen 5 ve 8 yıllık sağ- kalımın sırasıyla \%49,2, \%42 olduğunu ve sağ kalımı ileri yaşın ve ileri T evresinin belirlediğini bildirmişlerdir. Çalışmamızda postoperatif mortalite izlenmedi, ortalama sağkalım 17,9 aydı.

Nadir görülen bir tümör olması nedeniyle BHNK'lerde tedavi konusunda bir fikir birliği yoktur. Multimodalite tedavilere rağmen prognoz ve sağ kalım sağkalım sonuçları kötüdür. Neoadjuvan veya adjuvan kemoterapi alan grupta sağkalım avantajı olduğu görülmüştür. Erken evrede cerrahi uygulanan hastalarda adjuvan onkolojik tedaviye rağmen nüks ve metastazoranıyüksektir(7-9). Hatta perioperatifkemoterapinin (ilk 24 saat ile ilk 7 gün arasında) cerrahi uygulanan BHNEK'li olgularda faydalı olduğunu göstermektedir. Adjuvan, definitif torakal radyoterapi veya profilaktik kranial radyoterapi konusunda henüz netleşmiş bir fikir birliği yoktur. Multimodal tedavinin sağkalıma katkısının olduğu düşünülmektedir (10). Çalışmamıza dahil edilen olguların, üçüne neoadjuvan kemoterapi, tamamına adjuvan onkolojik tedavi ( tamamına adjuvan $\mathrm{KT}$, yedisine adjuvan $\mathrm{RT}$ ) uygulandı.

Bu nadir ve agresif seyirli tümörün etyolojisinde, epidermal büyüme faktörü reseptör (EGFR) geni, K-ras, TTF-1, C-Raf-1 ve ya nörotrofik tirozin reseptör kinaz (NTRK) gibi genlerde oluşan mutasyonlarında olduğu gösterilmiştir $(11,12)$ BHNEK'de moleküler belirteçlere göre hedefe yönelik tedavileri henüz test aşamasında olsa da, bu tedavilerdeki gelişmelerin multimodalite tedavilerine eklenmesi sayesinde gelecekte daha başarılı sağ kalım sonuçları elde edilebileceğini düşünüyoruz (13).

Rezeksiyon uygulanan BHNEK'li olgularda nüks veya metastaz sıklıkla lenf nodlarına, ipsilateral veya kontrolateral akciğere, beyine ve ya kemiklere olmaktadır (14). Bizim çalışmamızda en sık metastazın beyine (\% 25) ve kemiğe (\% 25) olduğu bulunmuştur (Tablo 1).

Akciğerin nöroendokrin tümörleri grubunda yer alan BHNEK'lar nadir görülmekle birlikte agresif biyolojik davranışları sebebiyle uygulanan multimodal tedavilere rağmen genel sağ kalım ve hastalıksız sağ kalım sürelerinin oldukça kısa olduğu görülmektedir. Ayrıca tanı anında KHAK'ları gibi, yüksek oranda lenf nodu (\%60-80) ve uzak metastaz (\%40) yapma potansiyeline sahiptirler. Ek olarak her ikisinde de sağkalım diğer KHDAK'lerden daha düşüktür. Potansiyel olarak rezeke edilebilen evre I BHNEK'li hastalarda bile \%27'den \%67'ye varan 5 yıllık sağ-kalım oranları ile prognoz kötüdür. Perioperatif kemoterapinin (ilk 24 saat ile ilk 7 gün arasında) rezeke edilen BHNEK'lu hastalarda sağ- kalıma katkı sağladığı bildirilmektedir. Yine de tedavide bir fikir birliği yoktur (9-15). Çalışmamızda anatomik cerrahi rezeksiyon sonrası uygulan adjuvan onkolojik tedavilere rağmen ortalama sağ kalım 17,9 \pm 19,04 ay (dağılım 2-72 ay), hastalıksız sağ kalım 15,08 \pm 19,6 ay ( dağılım 1-72 ay ) ve 5 yıllık sağ kalım ise \% 8,3 olarak hesaplandı.

\section{Sonuç}

Sonuç olarak BHNEK'lar, patolojik tanının zor olduğu, nadir görülen akciğer kanserleridir. Tedavi ve sağ-kalım açısından KHAK benzer özellikler taşısa da, tedavi stratejisinde tam 
olarak bir fikir birliğinin sağlanamamıştır. Cerrahiyle birlikte multimodal tedaviler prognozu olumlu yönde etkilemektedir. Evre 1 hastalıkta dahi adjuvan kemoterapinin prognozu olumlu yönde etkileyebileceği bilinmektedir. Günümüzde küratif anatomik rezeksiyonlar ve beraberinde eklenecek onkolojik tedaviler uzun dönem sağ-kalım için tek şans gibi gözükmektedir. Hedefe yönelik onkolojik tedaviler, gelecek için umut oluştursa da; bu nadir görülen tümörlerle ilgili daha geniş vaka serilerini içeren çalışmalara ihtiyaç vardır.

\section{Çıkar çatışması / finansal destek beyanı}

Bu yazıdaki hiçbir yazarın herhangi bir çıkar çatışması yoktur. Yazının herhangi bir finansal desteği yoktur.

\section{Kaynaklar}

1. Rekhtman N. Neuroendocrine tumors of the lung: an update. Arch Pathol Lab Med 2010; 134:1628-38.

2. lyoda A, Hiroshima K, Baba M et al. Pulmonary large cell carcinomas with neuroendocrine features are high-grade neuroendocrine tumors. Ann Thorac Surg 2002; 73: 1049-54.

3. Travis WD, Brambilla EW, Burke AP et al. WHO Classification of Tumours of the Lung, Pleura, Thymus, and Heart IARC Press, Lyon 2015.

4. Fernandez FG, Battafarano RJ. Large-cell neuroendocrine carcinoma of the lung. Cancer Control 2006; 13: 270-75.

5. Skuladottir H, Hirsch FR, Hansen HH, Olsen JH. Pulmonary neuroendocrine tumors: incidence and prognosis of histological subtypes: a populationbased study in Denmark. Lung Cancer 2002; 37: 127-35.

6. Shin AR., Shin B.K., Choi J.-A., Oh Y.W., Kim H.K., Kan EY. Large cell neuroendocrine carcinoma of the lung: radiologic and pathologic findings, J Comput Assist Tomogr, 2000; 24: 567-73

7. Fournel $L$, Falcoz PE, Alifano M, Charpentier MC, Boudaya MS, Magdeleinat $P$ et al. Surgical management of pulmonary large cell neuroendocrine carcinomas: a 10-year experience. European Journal of Cardio-Thoracic Surgery 2013; 43: 111-14
8. Sakurai $H$, Asamura $H$. Large-cell neuroendocrine carcinoma of the lung: surgical management. Thoracic Surgery Clinics 2014; 24: 305-11.

9. Fasano $\mathrm{M}$, Corte $\mathrm{CMD}$, Papaccio $\mathrm{F}$ et al. Pulmonary large cell neuroendocrine carcinoma From epidemiology to therapy. J Thor Oncol 2015; 10: 1133-41.

10. Rieber J, Schmitt J, Warth A, Muley T, Kappes J, Eichhorn F et al. Outcome and prognostic factors of multimodal therapy for pulmonary large-cell neuroendocrine carcinomas. European Journal of Medical Research 2015; 20: 2-8.

11. Sakai $Y$, Yamasaki T, Kusakabe $Y$, Kasai D, Kotani $Y$ et al. Largecell neuroendocrine carcinoma of lung with epidermal growth factor receptor (EGFR) gene mutation and co-expression of adenocarcinoma markers: a case report and review of the literature. Multidiscip Respir Med 2013; 8: 8-47.

12. Marchetti A, Felicioni L, Pelosi G, Del Grammastro M, Fumagalli $C$ et al. Frequent mutations in the neurotrophic tyrosine receptor kinase gene family in large cell neuroendocrine carcinoma of the lung. Hum Mutat 2008; 29: 609-16.

13. lyoda A, Travis WD, Sarkaria IS, Jiang SX, Amano H, Sato $Y$ et al. Expression profiling and identification of potential molecular targets for therapy in pulmonary large-cell neuroendocrine carcinoma. Exp Ther Med 2011; 2: 1041-45.

14. Ustaalioglu BBO, Ulas A, Esbah O, Turan N, Bilici A, Demirci U. Large cell neuroendocrine carcinoma: retrospective analysis of 24 cases from four oncology centers in Turkey. Thoracic Cancer 2013; 4: $161-166$

15. Iyoda A, Hiroshima K, Moriya Y et al. Postoperative recurrence and the role of adjuvant chemotherapy in patients with pulmonary large-cell neuroendocrine carcinoma. J Thorac Cardiovasc Surg 2009; 138: 446-53. 